Research Paper

\title{
Evaluation of the antibacterial potential of Petroselinum crispum and Rosmarinus officinalis against bacteria that cause urinary tract infections
}

\author{
Fernanda Villas Boas Petrolini ${ }^{1}$, Rodrigo Lucarini ${ }^{1}$, Maria Gorete Mendes de Souza ${ }^{1}$, \\ Regina Helena Pires ${ }^{1}$, Wilson Roberto Cunha ${ }^{2}$, Carlos Henrique Gomes Martins ${ }^{1}$ \\ ${ }^{1}$ Núcleo de Pesquisa em Ciências Exatas e Tecnológicas, \\ Laboratório de Pesquisa em Microbiologia Aplicada, Universidade de Franca, Franca, SP, Brazil. \\ ${ }^{2}$ Núcleo de Pesquisa em Ciências Exatas e Tecnológica, Grupo de Pesquisa em Produtos Naturais, \\ Universidade de Franca, Franca, SP, Brazil.
}

Submitted: February 23, 2012; Approved: September 10, 2012.

\begin{abstract}
In this study we evaluated the antibacterial activity of the crude hydroalcoholic extracts, fractions, and compounds of two plant species, namely Rosmarinus officinalis and Petroselinum crispum, against the bacteria that cause urinary tract infection. The microdilution method was used for determination of the minimum inhibitory concentration (MIC) and minimum bactericidal concentration (MBC). The crude hydroalcoholic extract of $R$. officinalis displayed in vitro activity against Gram-positive bacteria, with satisfactory MBC for the clinical isolate $S$. saprophyticus. The fractions and the pure compound rosmarinic acid did not furnish promising results for Gram-negative bacteria, whereas fractions 2, 3, and 4 gave encouraging results for Gram-positive bacteria and acted as bactericide against S. epidermidis as well as E. faecalis (ATCC 29212) and its clinical isolate. R. officinalis led to promising results in the case of Gram-positive bacteria, resulting in a considerable interest in the development of reliable alternatives for the treatment of urinary infections.
\end{abstract}

Key words: antibacterial activity, bioassay, Rosmarinus officinalis, Petroselinum crispum, Urinary Tract Infections (UTI).

\section{Introduction}

Urinary tract infections (UTIs) consist of the microbial invasion of any tissue of the urinary tract from the urethra to the kidneys. Infections of the prostate and epididymis are also often included in this definition (Ronald et al., 2001; Farrel et al., 2003).

The UTI etiology may vary according to sex, age, previous use of antibiotics, and contamination within or outside the hospital, not to mention that they differ from one environment to another. The microorganisms that mainly account for UTI are the Gram-negative enteric bacteria, especially Escherichia coli, which is the most frequently studied microorganism, followed by other Gramnegative bacteria such as Klebsiella sp, Enterobacter sp, Acinetobacter sp, Proteus sp, and Pseudomonas sp (Foxman, 2010; George and Manges, 2010). In addition, Staph- ylococcus saprophyticus, a Gram-positive bacterium, has been shown to be the second most frequent cause of UTI. The latter microorganism has also been demonstrated to be a saprophyte of the commensal flora of the urinary tract, mucosa, and skin, like $S$. epidermidis (Faro and Fenner, 1998; Mehnert-Kay, 2005).

The use of medicinal plants has become increasingly widespread and has been enriched by the vast biodiversity and the mixing of indigenous, African, and European cultures (Oliveira et al., 2003). The antimicrobial properties of plant extracts and isolated compounds have been investigated by a number of researchers worldwide (More et al., 2008; Porto et al., 2009; Al-Bakri et al., 2010). In Brazil, the consumption of herbal medicines is growing at a rate of $20 \%$ a year, following the re-evaluation of the global use of medicinal plants for the treatment of several diseases (Cartaxo et al., 2010). 
Parsley (Petroselinum crispum) is a member of the Umbelliferae family, and it has been employed in the food, pharmaceutical, perfume, and cosmetics industries (López et al., 1999). It is popularly known as cilantro, salsa, and salsa-pea. In traditional medicine, it is considered to be a diuretic, uterine stimulant, sedative, emollient, and anti-parasitic agent, and it is commonly employed for the treatment of chronic bronchitis, bronchial asthma, and dyspepsia. Its leaves and stems are indicated in the cases of menstrual problems, cystitis, edema, kidney stones, prostatitis, cramps, indigestion, anorexia, arthritis, and rheumatism (Yarnell, 2002; Yanardag et al., 2003; Wright et al., 2007). The constituents of parsley, which include ascorbic acid, carotenoids, flavonoids, coumarins, myristicin, apiole, various terpenoic compounds, phenyl propanoids, phthalides, furano coumarins and tocopherol, have been chemically investigated (Tunali et al., 1999; Yanardag et al., 2003).

Popularly known as rosemary, the Rosmarinus officinalis plant has been more often utilized due to religious reasons and it is commonly employed as a ritual ornament for deities and human beings. Its virtues were discovered in the Middle Ages, and since then it has been widely used for culinary and medicinal purposes worldwide (Leal et al., 2003; Ozcan, 2003; González-Trujano et al., 2007). Its main constituents are rosmarinic acid, carnosic acid, carnosol, ursolic acid, oleanolic acid, genkwanin, apigenin, and luteolin (Lamaison et al., 1991; Cuvelier et al., 1996; Frankel et al., 1996).

Because there has been a considerable rise in the prevalence of infectious diseases caused by bacterial resistance, researchers have become more and more engaged in the search for new effective antimicrobials from plant sources. A survey of the literature, namely the works of Ojala et al. (2000), Oluwatuy et al. (2004), Bozin (2007), Fu et al. (2007), Weckesser et al. (2007), and Silva et al. (2008) did not retrieve any information on the use of $P$. crispum and $R$. officinalis for the treatment of bacterial UTI. Therefore, this study aimed to evaluate the antibacterial activity of the crude hydroalcoholic extracts, fractions, and compounds of two plant species, namely Rosmarinus officinalis and Petroselinum crispum, against the bacteria that cause UTI.

\section{Material and Methods}

\section{Microorganisms}

To determine the antibacterial activity of the crude extracts, fractions, and substances isolated from the plant species investigated here, the following strains from the American Type Culture Collection (ATCC) were employed: Escherichia coli (ATCC 25922), Proteus mirabilis (ATCC 29906), Klebsiella pneumoniae (ATCC 10031), Enterobacter aerogenes (ATCC 13048), Pseudomonas aeruginosa (ATCC 14502), Staphylococcus saprophyticus (ATCC 35552), Staphylococcus epidermidis (ATCC
12228), Enterococcus faecalis (ATCC 29212), and their clinical isolates. The clinical bacterial isolates and standard strain (ATCC) used in this study were maintained at $-20^{\circ} \mathrm{C}$ in a freezer in the Laboratory of Research in Applied Microbiology (LaPeMA) of the University of Franca.

\section{Collection of crude extracts, fractions, and the pure compound rosmarinic acid}

The aerial parts of the plant species $R$. officinalis were collected $(3.5 \mathrm{~kg})$ in the urban area of Patrocínio, located in the western region of the Brazilian state of Minas Gerais in May 2007. The geographical position of the town is latitude $18^{\circ} 17^{\prime} 00^{\prime \prime} \mathrm{S}$, longitude: $46^{\circ} 59^{\prime} 36^{\prime \prime} \mathrm{W}$; average height of 972 meters.

The aerial parts of the plant species $P$. crispum were collected $(4 \mathrm{~kg})$ from a traditional garden, located in the city of Guaxupé, located in southern region of the Brazilian state of Minas Gerais in October 2007. The geographical position of the town is latitude $21^{\circ} 18^{\prime} 20^{\prime}$ ' $\mathrm{S}$, longitude $46^{\circ} 42^{\prime} 41^{\prime \prime} \mathrm{W}$; average elevation of 830 meters.

Both plants were identified by Prof. Dr. Milton Groppo, Faculdade de Filosofia, Ciências e Letras de Ribeirão Preto, University of São Paulo (FFCLRP-USP), and a voucher specimen was deposited in the herbarium of the Institution, labeled as SPRF 11911 th plant species P. crispum and SPRF 11912th plant species $R$. officinalis.

The plants were dried and stabilized in circulating air oven at a temperature of about $40{ }^{\circ} \mathrm{C}$, followed by grinding to a powder in a knife mill (Marconi, Piracicaba, São Paulo, Brazil). The powder resulting from each plant was subjected to exhaustive extraction by maceration with ethanol (Merck KgaA, Darmstadt, Germany)/water (96:4 v/v) at room temperature. A hydro solvent was employed, in order to obtain more polar substance(s). Three successive extractions were accomplished, with one-week interval between them. All the material resulting from the maceration process was filtered and concentrated under reduced pressure at $60{ }^{\circ} \mathrm{C}$ until complete elimination of the solvent, using a rotary evaporator (Marconi, Piracicaba, São Paulo, Brazil).

The dried plant extracts were placed in an amber bottle covered with a lid and were stored in the refrigerator until the tests were conducted. Fractionation of the extract of $R$. officinalis $(12.0 \mathrm{~g})$ was performed by vacuum liquid chromatography (VCL-silica gel 60, Merck) using $n$-hexane, ethyl acetate, ethanol (all purchased from Merck), or mixtures of these solvents in increasing polarity gradient as eluent, which furnished seven fractions. A volume of two liters of solvent or solvent mixtures was necessary for the collection of each fraction. Fractions 1, 2, 3, 4, 5, 6, and 7 were eluted with $n$-hexane, hexane/ethyl acetate $(75: 25 \mathrm{v} / \mathrm{v})$, hexane/ethyl acetate $(50: 50 \mathrm{v} / \mathrm{v})$, ethyl acetate, ethyl acetate/ ethanol $(75: 25 \mathrm{v} / \mathrm{v})$, ethyl acetate/ ethanol $(50: 50 \mathrm{v} / \mathrm{v})$, and ethanol, respectively, which yielded masses of $0.4,2.4,4.4,1.8,0.6,0.7$, and $0.5 \mathrm{~g}$, respectively. 
A yellowish solid substance, namely rosmarinic acid (designated RA), was isolated from the extraction. To this end, $200 \mathrm{~g}$ powdered leaves of the plant that had been submitted to extraction by maceration (room temperature) for seven days using water/acetic acid (85:15 v/v) were employed. The product of maceration was filtered, and the $\mathrm{pH}$ was adjusted to 10 by addition of a calcium hydroxide (Merck) solution. This gave a precipitate $(27 \mathrm{~g})$ that was identified by comparison with an authentic RA sample. The final identification was carried out by ${ }^{1} \mathrm{H}$ and ${ }^{13} \mathrm{C}$ NMR. The data were compared to those published for rosmarinic acid (Kuhnt et al., 1995), which confirmed that RA was actually rosmarinic acid.

\section{Biological assays}

To evaluate the antibacterial activity of the crude extracts, fractions, and the isolated substance, the Minimum Inhibitory Concentration (MIC) was determined by the microdilution technique performed in 96-well microtiter plates (Techno Plastic Products, Trasadingen, Switzerland), as recommended by the CLSI (2006). For dilution of the extracts, fractions, and isolated compound, one milligram of the samples was dissolved in $125 \mu \mathrm{L}$ dimethyl sulfoxide (DMSO). Controls were monitored in culture. Sterility was controlled by means of the Mueller-Hinton broth (Difco, Sparks, MD, USA). The negative control was the solvent dimethyl sulfoxide (DMSO), used at concentrations ranging from 1 to $5 \%$. In the case of the positive control, the antibiotics gentamicin and penicillin (Merck Sharp \& Dohme, São Paulo, Brazil) were employed for Gramnegative and Gram-positive bacteria, respectively, at concentrations ranging from $0.0115 \mathrm{~g} / \mathrm{mL}$ to $5.9 \mu \mathrm{g} / \mathrm{mL}$.

The use of the controls allowed for analysis validation. The crude extracts, fractions, and pure compound were evaluated at concentrations between $20 \mu \mathrm{g} / \mathrm{mL}$ and $400 \mu \mathrm{g} / \mathrm{mL}$. To this end, microplates were capped and incubated at $37^{\circ} \mathrm{C}$, for 24 hours. Following this incubation period, $15 \mu \mathrm{L}$ of a resazurin (Sigma-Aldrich, New York, USA) solution at $0.02 \%$ in sterile water was added to each well, for analysis of the results. This system facilitates microbial growth detection; the blue color indicates the absence of microbial growth, while the red color indicates growth of viable cells. For determination of the Minimal Bactericidal Concentration (MBC), before the addition of resazurin an aliquot of the inoculum was aseptically removed from each well presenting no apparent growth, and then plated onto agar Mueller-Hinton (Difco) supplemented with sheep blood (5\%); the plates were incubated as previously described.

\section{Results and Discusssion}

The crude extract obtained from the leaves and stems of the plant species $P$. crispum furnished MIC and $\mathrm{MBC}>400 \mu \mathrm{g} / \mathrm{mL}$ for all the tested bacterial strains, ex- cept for $P$. aeruginosa (ATCC 14502), which yielded MIC and $\mathrm{MBC}$ of $350 \mu \mathrm{g} / \mathrm{mL}$ and $>400 \mu \mathrm{g} / \mathrm{mL}$, respectively, which resulted in a bacteriostatic effect. Therefore, the plant extract obtained from $P$. crispum did not furnish promising results against the selected bacteria. Rios and Recio (2005) described that the crude extract of a plant can only be considered promising when $\mathrm{MIC}<100 \mu \mathrm{g} / \mathrm{mL}$ is achieved (Table 1).

The hydroalcoholic extract from $R$. officinalis leaves led to satisfactory results according to the criteria of Rios and Recio (2005) for the Gram-positive bacteria $S$. saprophyticus (ATCC 35552), S. epidermidis (ATCC 12228), E. faecalis (ATCC 29212), and their clinical isolates, for which the MIC values ranged from 70 to $150 \mu \mathrm{g} / \mathrm{mL}$. Analysis of the MBC results revealed bactericidal activity against $S$. saprophyticus and bacteriostatic effect against the other tested Gram-positive bacteria. For Gram-negative bacteria, though, results were not so promising. MIC and MBC were $>400 \mu \mathrm{g} / \mathrm{mL}$, with the exception of the bacterium $P$. aeruginosa (ATCC 14502), for which there was a bacteriostatic effect (Table 1).

The encouraging results obtained with the crude extract of $R$. officinalis motivated its fractionation by vacuum liquid chromatography, which enabled assessment of the bactericidal activity of these fractions. Fractionation of the plant $R$. officinalis gave rise to 7 fractions, designated fractions 1 to 7 . In the present study, the compound rosmarinic acid was also isolated from $R$. officinalis leaves (Figure 1).

Fractions 1-7 afforded MIC values ranging between 200 and $400 \mu \mathrm{g} / \mathrm{mL}$ in the case of Gram-negative bacteria, while $\mathrm{MBC}$ was equal to or larger than $400 \mu \mathrm{g} / \mathrm{mL}$ for all the tested bacteria. As for Gram-positive bacteria, fraction 4 followed by fractions 2 and 3 gave the best results, with MIC values lying between 30 and $400 \mu \mathrm{g} / \mathrm{mL}$ ( $S$. saprophyticus, $S$. epidermidis and E. faecalis). The remaining fractions and the isolated compound rosmarinic acid yielded MIC values ranging from 70 to $400 \mu \mathrm{g} / \mathrm{mL}$. The $\mathrm{MBC}$ values revealed the bactericidal effects of fraction 3 against the Gram-positive bacterium E. faecalis (ATCC 29212) and its clinical isolate, and of fractions 2 and 3 against the Gram-positive bacterium $S$. epidermidis (ATCC 12228), which represents an improvement compared with the crude extract. It is considered that a bacteriostatic effect occurs when the MIC/MBC ratio is lower than 1 and a bactericidal effect is said to take place when the MIC/MBC ratio is equal to or greater than 1 (Table 1).

Many studies have reported that antibacterial activity investigation is based on folk medicine; that is, the selection of plants to be tested is based on the knowledge of various populations about the curative power of the plants. Some researchers, more specifically Ojala et al. (2000), Oluwatuy et al. (2004), Bozin et al. (2007), Fu et al. (2007), Weckesser et al. (2007), and Silva et al. (2008), have described the antibacterial activity of spices. 


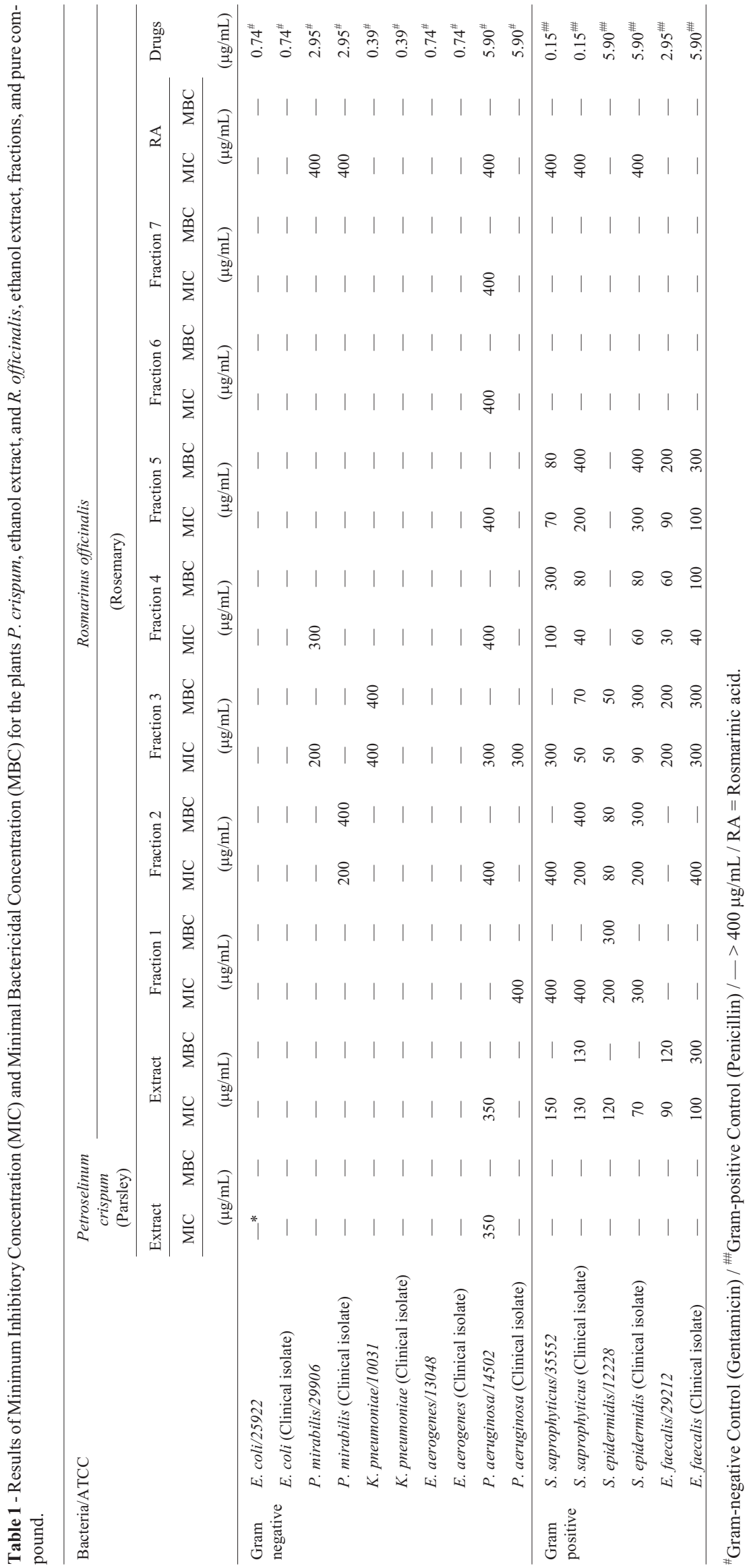




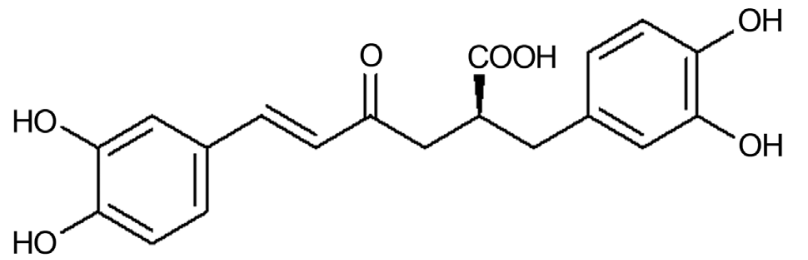

Figure 1 - Chemical structure of rosmarinic acid.

On the basis of MIC determination, Ojala et al. (2000) reported the antimicrobial activity of the methanol extract of the plant species $P$. crispum, containing coumarins, against the clinical isolates Bacillus subtilis, $P$. aeruginosa, S. epidermidis, S. aureus, and Saccharomyces cerevisiae. According to these authors, a modest antimicrobial activity, with MIC ranging from $200 \mu \mathrm{g} / \mathrm{mL}$ to $350 \mu \mathrm{g} / \mathrm{mL}$, was achieved. Using the hydroalcoholic of this same plant, our group obtained the same MIC values against the standard strain of $P$. aeruginosa.

Oluwatuy et al. (2004) demonstrated the antibacterial activity of the methanol extract of $R$. officinalis against the clinical isolate of $S$. aureus, with MIC of $60 \mu \mathrm{g} / \mathrm{mL}$. Bozin et al. (2007) showed that the Gram-positive S. aureus (ATCC 6538) and S. epidermidis (ATCC 12228) were sensitive to the essential oil from the plant species $R$. officinalis, with MIC values equal to $60 \mu \mathrm{g} / \mathrm{mL}$ and $150 \mu \mathrm{g} / \mathrm{mL}$, respectively. According to $\mathrm{Fu}$ et al. (2007), combinations of two essential oils from $R$. officinalis displayed antibacterial activity against $S$. epidermidis (ATCC 12228), S. aureus (ATCC 6538), B. subtilis (ATCC 6633), E. coli (ATCC 8739), P. vulgaris (ATCC 49132), and $P$. aeruginosa (ATCC 27853), with MIC ranging from $70 \mu \mathrm{g} / \mathrm{mL}$ to $150 \mu \mathrm{g} / \mathrm{mL}$.

Silva et al. (2008) investigated the action of the hydroalcoholic extract of $R$. officinalis on Streptococcus mitis (ATCC 9811), Streptococcus sanguinis (ATCC 10556), Streptococcus mutans (ATCC 25175), and Streptococcus sobrinus (ATCC 27609), the predominant bacterial species in the supragingival biofilm, and Lactobacillus casei (ATCC 7469), obtained by the MIC technique. The MIC values lay between 40 and $120 \mu \mathrm{g} / \mathrm{mL}$, except for $S$. mitis (ATCC 9811), which yielded MIC greater than 400 $\mu \mathrm{g} / \mathrm{mL}$. According to these authors, the rosemary extract was effective against the tested strains, whereas in our study the selected bacterial strains did not give evidence of such promising results in the case of the hydroalcoholic extract. Nevertheless, good results were verified in the case of Gram-positive bacteria belonging to the species $S$. epidermidis and E. faecalis.

Thus, the results of these studies suggest that different organisms react differently to the same extract, as well as fractions and pure compounds. The plant $P$. crispum did not lead to satisfactory results for the bacteria tested herein, while the plant $R$. officinalis furnished promising results, particularly for Gram-positive bacteria. Taken together and compared with published data (Rios and Recio, 2005), these findings justify the considerable interest in the development of credible alternatives for the treatment of urinary tract infections.

\section{Acknowledgments}

The authors thank the Brazilian foundation FAPESP (Proc. 2008/05140-7) for financial support and CNPq for fellowships.

\section{References}

Al-Bakri AG, Othman G, Afifi FU (2010) Determination of the antibiofilm, antiadhesive, and anti-MRSA activities of seven Salvia species. Pharmacogn Mag 6:264-270.

Bozin B, Dukic NM, Samojlik I, Jovino E (2007) Antimicrobial and antioxidant properties of rosemary and sage (Rosmarinus officinalis L. and Salvia officinalis L., Lamiaceae) essential oils. J Agric Food Chem 55:7879-7885.

Cartaxo SL, Souza MM, De Albuquerque UP (2010) Medicinal plants with bioprospecting potential used in semi-arid northeastern Brazil. J Ethnopharmacol 131:326-342.

Clinical and Laboratory Standards Institute (2006) CLSI Document M7-A7: Methods for Dilution Antimicrobial Susceptibility Tests for Bacteria That Grow Aerobically, CLSI, Wayne, PA.

Cuvelier ME, Richard H, Berset C (1996) Antioxidative activity and phenolic composition of pilot-plant and commercial extracts of sage and rosemary. J Am Oil Chem Soc 73:645652.

Faro S, Fenner DE (1998) Urinary tract infections. Clin Obstet Gynecol 41:744-754.

Farrel DJ, Morrissey I, De Rubeis D, Robbins M, Felmingham G (2003) The United King multicentre study of the antimicrobial susceptibility of bacterial pathogens causing urinary tract infection. Am J Infect Control 46:94-100.

Foxman B (2010) The epidemiology of urinary tract infection. Nat Rev Urol 7:653-660.

Frankel EN, Huang S, Aeschbach R, Prior E (1996) Antioxidant activity of a rosemary extract and its constituents, carnosic acid, carnosol, and rosmarinic acid, in bulk oil and oil-inwater emulsion. J Agric Food Chem 44:131-135.

Fu Y, Zu Y, Chen L, Shi X, Wang Z, Sun S, Efferth T (2007) Antimicrobial activity of clove and rosemary essential oils alone and in combination. Phytother Res 21:989-994.

George DB, Manges AR (2010) A systematic review of outbreak and non-outbreak studies of extraintestinal pathogenic Escherichia coli causing community-acquired infections. Epidemiol Infect 138:1679-1690.

González-Trujano ME, Peña EI, Martínez AL, Moreno J, Guevara-Fefer P, Déciga-Campos M, López-Muñoz FJ (2007) Evaluation of the antinociceptive effect of Rosmarinus officinalis L. using three different experimental models in rodents. J Ethnopharmacol 11:476-482.

Kuhnt M, Pröbstle A, Rimpler H, Bauer R, Heinrich M (1995) Biological and pharmacological activities and further constituents of Hyptis verticillata. Planta Med 61:227-232. 
Lamaison JL, Petitjean-Freytet C, Carnat A (1991) Medicinal Lamiaceae with antioxidant properties, a potential source of rosmarinic acid. Pharm Acta Helv 66:185-188.

Leal PF, Braga ME, Sato DN, Carvalho JE, Marques MO, Meireles MA (2003) Functional properties of spice extracts obtained via supercritical fluid extraction. J Agric Food Chem 51:2520-2525.

López MG, Sánchez-Mendoza IR, Ochoa-Alejo N (1999) Compartive study of volatile components and fatty acids of plants and in vitro cultures of parsley (Petroselinum crispum (Mill) nym ex hill). J Agric Food Chem 47:3292-3296.

Mehnert-Kay SA (2005) Diagnosis and management of uncomplicated urinary tract infections. Am Fam Physician 72:451-456.

More G, Tshikalange TE, Lall N, Botha F, Meyer JJ (2008) Antimicrobial activity of medicinal plants against oral microorganisms. J Ethnopharmacol 119:473-477.

Ojala T, Remes S, Haansuu P, Vuorela H, Hiltunen R, Haahtela K, Vuorela P (2000) Antimicrobial activity of some coumarin containing herbal plants growing in Finland. J Ethopharmacol 73:299-305.

Oliveira CF, Junqueira RG, Stehmann JR, Brandão MGL (2003) Potential of medicinal plants as a source of new antimalarial drugs: species listed in the bibliography Ethno Brazil. Braz J Med Biol Res 5:23-31.

Oluwatuy M, Katz GW, Gibbons S (2004) Antibacterial and resistance modifying activity of Rosmarinus officinalis. Phytochem 65:3249-3254.

Ozcan M (2003) Antioxidant activities of rosemary, sage, and sumac extracts and their combinations on stability of natural peanut oil. J Med Food 6:267-270.

Porto TS, Furtado NA, Heleno VC, Martins CH, Da Costa FB, Severiano ME, Silva NA, Veneziani RC, Ambrósio SR
(2009) Antimicrobial ent-pimarane diterpenes from Viguiera arenaria against Gram-positive bacteria. Fitoterapia $80: 432-436$.

Rios JL, Recio MC (2005) Medicinal plants and antimicrobial activity. J Ethnopharmacol 100:80-84.

Ronald AR, Nicolle LE, Stamm E, Krieger J, Warren J, Schaeffer A, Naber KG, Hooton TM, Johnson J, Chambers S, Andriole V (2001) Urinary tract infection in adults: research priorities and strategies. Int J Antimicrob Agents 17:343-348.

Silva MSA, Silva MAR, Higino JS, Pereira MSV, Carvalho AAT (2008) Atividade antimicrobiana e antiaderente in vitro do extrato de Rosmarinus officinalis Linn. sobre bactérias orais planctônicas. Rev Bras Farmacogn 18:236-240.

Tunali T, Yarat A, Yanardag R, Ozçelik F, Ozsoy O, Ergenekon G, Emekli N (1999) Effect of parsley (Petroselinum crispum) on the skin of STZ induced diabetic rats. Phytother Res 13:138-141.

Weckesser S, Engel K, Simon-Haarhaus B, Wittmer A, Pelz K, Schempp CM (2007) Screening of plant extracts for antimicrobial activity against bacteria and yeasts with dermatological relevance. Phytomedicine 14:508-516.

Wright CI, Van-Buren L, Kroner CI, Koning MM (2007) Herbal medicines as diuretics: a review of the scientific evidence. $\mathrm{J}$ Ethnopharmacol 114:1-31.

Yanardag R, Bolkent S, Tabakoglu-Oguz A, Ozsoy-Saçan O (2003) Effects of Petroselinum crispum extract on pancreatic $B$ cells and blood glucose of streptozotocin-induced diabetic rats. Biol Pharm Bull 26:1206-1210.

Yarnell E (2002) Botanical medicines for the urinary tract. World J Urol 20:285-293.

All the content of the journal, except where otherwise noted, is licensed under a Creative Commons License CC BY-NC. 